has gleaned information which indicates that several nonneoplastic conditions exhibit even more striking patterns of distribution which warrant further study.

The statistical purist may well comment that figures for cancer incidence based on such evidence are useless. We do not believe this to be true, and we feel that in an area such as this every factual piece of knowledge is of value.

\section{Summary}

Carcinoma of the penis, Kaposi's sarcoma, squamous-cell carcinoma of the skin, oesophageal cancer, and gastric carcinoma have a variable incidence in different parts of Uganda and probably in other areas of East Africa. General statements about cancer in Africans should therefore be accepted with reserve. More accurate figures are needed before studies on aetiology can be started. These figures may be attained by a combined approach on the part of the clinician and pathologist. Personal contact is an essential feature of such a programme.

Our thanks are due first to the Ministries of Health of Uganda, Kenya, Tanzania, and Rwanda for their permission to make these safaris and to visit Government hospitals. We would also like to thank all the doctors in both Government and Mission hospitals throughout East Africa for giving up valuable time to discuss their work. Finally, we would like to thank all our colleagues in the New Mulago Hospital and the Makerere University College Medical School for their help, advice, and co-operation. We would also like to acknowledge our debt to Professor J. N. P. Davies, who initiated this type of work in East Africa.
Financial support for these activities has been provided by the Medical Research Council and the British Empire Cancer Campaign.

Figs. 1 and 2 are acknowledged to the Department of Medical Illustration, Makerere University College Medical School.

Our thanks are due to Mrs. Barbara Wright, cancer registrar, for the figures shown in the Table.

\section{REFERENCES}

Ahmed, N. (1965). Personal communication.

Bundschuh, M. (1964). Personal communication.

Burkitt, D. P., Nelson, C. L., and Williams, E. H. (1963). E. Afr. med. F., 40,1 .

Ceuterick, J. (1960). Trop. geogr. Med., 12, 119.

Chopra, S. A. (1964). Personal communication.

Clifford, P. (1964). Personal communication.

da Cunha, A. P. J. (1965). Personal communication.

da Cunha, A. P. J. (1965). Personal communication. Collins. Butterworths, London.

Elmes, S., Hutt, M. S. R., Mtimavalye, L. A. R., Owor, R., and Shaper, L. (1964). Brit. med. F., 1, 259.

Wilson, B. A., and Knowelden, J. (1958). Ibid., 2, 439.

-1 (1962). Lancet, 2, 328.

De Souza, L. (1965). Personal communication.

Dodge, O. G., Linsell, C. A., and Davies, J. N. P. (1963). E. Afr. med. f., 40, 440 .

Gigasse, P. Clemmesen, J., and Maisin, J. (1962). Report to the University of Louvain, Belgian Congo.

Kyalwazi, S. K. (1964). Personal communication.

Mati, J. K. G., and Auma, S. (1964). Makerere med. F., 8, 38.

Miller, R. J. (1964). Personal communication.

Nevill, G. (1964). Personal communication.

Nillroth, L. W. (1964). Personal communication.

Ntuyabaliwe, W. K., and Mluge, G. (1965). Makerere med. F., 8, 18.

Oettlé, A. G. (1962). Acta un. int. Cancr., 16, 230.

Shepherd, J. (1965). Personal communication.

Slavin, G. (1965). Personal communication.

Slavin, G. (1965). Personal communication.

Taylor, J. (1964). Personal communication.
Williams, E. H. (1965). Personal communication.

\title{
Aetiology and Management of Bronchiolitis and Pneumonia in Childhood
}

\author{
F. M. ELDERKIN, $*$ M.R.C.P., M.R.C.P.ED., D.C.H. ; P. S. GARDNER, $\dagger$ M.D., DIP.BACT. ; \\ D. C. TURK, $\dagger$ D.M., M.R.C.P., M.C.PATH. ; ANITA C. WHITE, $\dagger$ B.SC.
}

Brit. med. F., 1965, 2, 722-727

In presenting our observations on bronchiolitis and pneumonia in children admitted to Newcastle upon Tyne hospitals during the winter of 1963-4 we are concerned with four problems.

1. Part Played by Viruses.-Infection with respiratory syncytial virus (R.S.V.) is now accepted as a common cause of acute disease of the lower respiratory tract, and our experience is in agreement with this (Chanock et al., 1961 ; Reilly et al., 1961 ; Adams et al., 1961 ; Holzel et al., 1963 ; Andrew and Gardner, 1963). It is not the only virus involved, and there are a substantial number of acute respiratory illnesses from which no infective agents have so far been isolated. More information is needed about the relative importance of the different viruses in different parts of the country in different years, and we felt that our experience in 1963-4 should be recorded.

2. Extent and Significance of Bacterial Infection.-A clear understanding of this subject is necessary if antibiotics are to be used rationally, but facts are few, and the conclusions of different workers contradictory. The main obstacle is the difficulty of obtaining, by methods suitable for routine use, specimens which

\footnotetext{
* Department of Child Health, Royal Victoria Infirmary and University of Newcastle upon Tyne.

† Department of Microbiology, Royal Victoria Infirmary and University of Newcastle upon Tyne.

$¥$ Now at Cumberland Infirmary, Carlisle.
}

give reliable information about the bacteriological condition of the lower respiratory tract, particularly as the answers obtained are distorted through children having received antibiotics before coming to hospital. The increasing importance of Staphylococcus aureus as a cause of pneumonia in infancy is well known. While assessing the contribution of this organism we felt it was also necessary to consider the claim by Wood et al. (1954) and Sell (1960) that capsulate strains of Haemophilus influenzae are responsible for bronchiolitis.

3. Causes of Death.-In England and Wales in 1962, 2,944 children died from "bronchitis and pneumonia," bronchiolitis being included in this total and not listed separately (RegistrarGeneral, 1963). These were one-sixth of all the deaths in childhood and one-quarter of those occurring after the first week of life. Yet, in many articles published in the past 10 years, accounts of the pathology in children who died are lacking or incomplete.

4. Rational Management of Children with Bronchiolitis.The extent to which management is rational will depend on how far we understand the full effect of the virus infection, the extent of bacterial intervention, and the disturbance of pulmonary function and other systemic disorders to which they give rise. In all these aspects knowledge is incomplete, yet no carefully controlled trials of the many remedies in common 
use have been made. We are particularly disturbed by the contrast between uncertainty about the role of bacteria and the widespread "routine" use of antibiotics. So far we have followed traditional methods of treatment and are well aware of the difficulties at this stage of achieving a more discriminating approach. We hope that this account of management and outcome in this series will encourage others to reconsider their therapeutic presuppositions and methods.

\section{Plan of Investigation}

All cases of bronchiolitis and pneumonia admitted to four Newcastle upon Tyne hospitals (Royal Victoria Infirmary, Walkergate Hospital, Newcastle General Hospital, and the Fleming Memorial Hospital) between 1 November 1963 and 30 June 1964 were studied. A clinical diagnosis was made on admission, based on the following definitions:

Acute Bronchiolitis.-An acute respiratory disease affecting infants and young children, and frequently occurring in epidemics. The main features are coryza lasting from 24 hours to several days followed by the swift development of illness with fever of variable degree, rapid respiration, frequent harsh exhausting cough, an expiratory wheeze, and in most cases widespread fine rales. Development of pulmonary distension, often with costal recession, is of special diagnostic significance. Radiographs show pulmonary distension in most cases, and linear areas of collapse in some.

Pneumonia.-An acute respiratory disease with fever, pallor or cyanosis, restlessness or prostration, variable cough, and rapid respiration, often with movement of the alae nasi. Clinical evidence of consolidation is present in a minority of affected children, the main signs in the lungs being diminished air entry and localized or widespread fine rales. There will be shadows in the radiographs suggesting lobular, segmental, or lobar consolidation.

We find that these clinical descriptions enable us to distinguish between acute bronchiolitis and primary pneumonia. The distinction between the less severe examples of bronchiolitis and acute bronchitis is sometimes difficult. We regard bronchitis as a respiratory illness of moderate severity, with cough as the main symptom and rhonchi as the main pulmonary sign. Marked dyspnoea, chest recession, and pulmonary distension, particularly in an infant, would suggest bronchiolitis. We recognize that these descriptive categories are not absolute and that clinicians will differ on individual cases, but we believe that the advantages of precise classification justify our attempt to achieve it.

\section{Materials and Methods}

A cough swab was collected from each child on admission, using a pair of swabs firmly bound together so that two specimens could be collected in a single operation with minimum distress to the child. One swab of the pair was then used for bacteriology. Detailed bacteriological studies of such swabs for the purpose of the present report were limited to those from the Royal Victoria Infirmary and Walkergate Hospital. The other swab of each pair was used for the immediate inoculation of Hanks's lactalbumin medium containing antibiotics. This was placed in a vacuum flask containing Cardice at the bedside, and was transported to the laboratory in due course, together with a specimen of faeces. As soon as possible, but always within 24 hours after the child's admission, a further swab was taken by one of us who visited the hospitals daily for this purpose. This was placed in Hanks's lactalbumin medium containing antibiotics and brought, unfrozen and without delay, to the laboratory for the immediate inoculation of suitable tissue-culture tubes. A specimen of blood for serological investigation was collected, usually by heel-stab, as soon as possible after admission, and a second specimen by the same method two to three weeks later.

\section{Bacteriology}

Admission swabs from children in the Royal Victoria Infirmary were sent immediately to the laboratory and used for the inoculation of two plates of blood agar and one plate of chocolate agar. These media, as routinely prepared in this laboratory, support good growth of staphylococci, haemophili, pneumococci, and haemolytic streptococci. To facilitate the detection and identification of haemophili, one of the blood-agar plates was especially spread and streaked with staphylococci as described by Turk (1963). Swabs from patients in Walkergate Hospital were used to inoculate chocolate-agar slopes in screwcapped bottles and also bottles of cooked-meat medium. These transport media were incubated at $37^{\circ} \mathrm{C}$. until it was possible to transfer them to the investigating laboratory, usually within 24 hours and always within 48 hours of their inoculation. They were then subcultured to the same media as were used for swabs collected in the Royal Victoria Infirmary. Preliminary trials had shown that all the likely bacterial pathogens survived satisfactorily when transported in this way. Cultures of specimens from both hospitals were seen by the same observer. All coagulase-positive staphylococci (Staph. aureus) were phage-typed, and all V-factor-dependent Gramnegative bacilli (haemophili) were subcultured to Levinthal's medium and examined for the iridescence on this medium which is characteristic of capsulate strains of $H$. influenzae.

\section{Virology}

Tissue-culture Cell Lines.-A line of "Bristol" HeLa cells originally obtained from Dr. J. O'H. Tobin, of Manchester, was grown in Eagle's medium containing $10 \%$ rabbit serum. The cells were maintained after inoculation in Medium 199 containing $2 \%$ rabbit serum. A line of Hep 2 cells developed in this laboratory ( $\mathrm{Pal}$ et al., 1963) was also used. This, too, was grown in Eagle's medium but containing $10 \%$ calf serum, and maintained in Medium 199 containing $2 \%$ calf serum. Monkeykidney cells were kindly supplied by the Medical Research Council, Biological Standards Laboratory, Hampstead, London. The cells were grown in Hanks's lactalbumin medium with $5 \%$ horse serum, and maintained in Medium 199. The last cell line, human embryonic lung (H.E.L.7), was obtained from Burroughs Wellcome Laboratory and was grown in Eagle's medium containing $10 \%$ calf serum, and maintained in Eagle's medium containing $2 \%$ calf serum (Taylor-Robinson and Bynoe, 1964).

Laboratory Procedure. $-0.2 \mathrm{ml}$. of medium from the unfrozen cough swabs was inoculated into two tubes of "Bristol" HeLa tissue-culture cells as soon as they arrived in the laboratory, which was usually within 30 minutes of leaving the patient. If possible they were also inoculated at this stage into Hep 2 and monkey-kidney cells. It was hoped in this way to isolate R.S.V. When they had been inoculated on to at least one cell line the specimens were stored at $-40^{\circ} \mathrm{C}$. until further suitable cells were available. $0.2 \mathrm{ml}$. of media from cough swabs which had been frozen was inoculated into Hep 2 and monkey-kidney cells. These cell lines were used to detect adenoviruses, enteroviruses, parainfluenza viruses, influenza viruses, and herpes simplex. H.E.L.7 tissue-culture cells and a second set of monkey-kidney cells were used for a limited number of specimens in an attempt to detect rhinoviruses. Both cell lines were maintained at $33^{\circ} \mathrm{C}$. on a roller drum. Monkey-kidney cells were tested by a haemadsorption test based on the original method of Vogel and Shelokov (1957) for the detection of influenza and parainfluenza viruses. Fertile hens' eggs were also used for the possible detection of influenza. 0.2 and $0.1 \mathrm{ml}$. of a $10 \%$ suspension of faeces were inoculated into monkey-kidney and Hep 2 cells for the detection of adenoviruses and enteroviruses. The identity of haemadsorption viruses was confirmed by, a haemadsorption-inhibition test. 
Cytopathogenic agents, including R.S.V., were identified by neutralization tests, and in the case of adenoviruses by a complement-fixation test as well. Detailed descriptions of the laboratory methods used, including the testing of paired sera by the complement-fixation test, have been published previously (Gardner et al., 1960, 1964 ; Andrew and Gardner, 1963).

\section{Laboratory Findings}

Virological investigations were undertaken on 106 children with bronchiolitis and 45 cases of pneumonia. Detailed bacteriological investigation for the purpose of this report was restricted to 39 cases of bronchiolitis and 26 cases of pneumonia in the Royal Victoria Infirmary and Walkergate Hospital. Cases of bronchiolitis which developed pneumonia are included only in the bronchiolitis group. The age distribution of all patients is shown in Table I.

TABLE I.-Age Distribution of 106 Patients With Bronchiolitis and 45

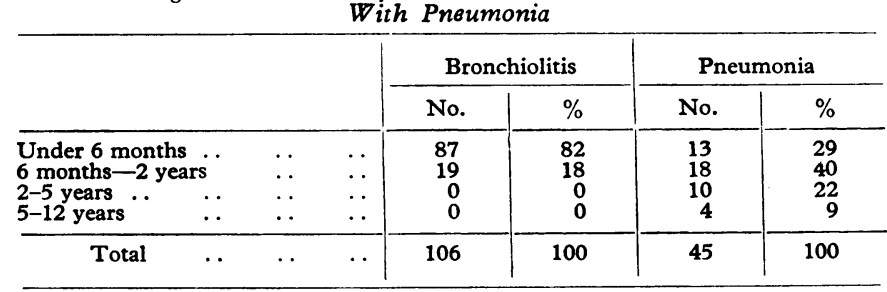

\section{Bacteriology}

Bronchiolitis.-Suitable admission swabs were received from 20 children with bronchiolitis in the Royal Victoria Infirmary and 19 in Walkergate Hospital. Staph. aureus of phage type $80 / 81$ and resistant to most antibiotics was recovered in pure culture from the admission swab of Case 2, a child in the Royal Victoria Infirmary. Two other admission swabs from the Royal Victoria Infirmary and seven from Walkergate Hospital yielded Staph. aureus, all of different phage types and mostly in mixed cultures. Four of the seven Walkergate isolates were recovered from the cooked-meat-medium cultures but not from the chocolate-agar slopes; it appears that the higher recovery rate of this species from Walkergate specimens may have been due to an enrichment effect of the cooked-meat medium or to dilution of antibiotics present in the specimens as a result of treatment before admission. The only haemolytic streptococcus isolated was of Lancefield's group G. Of six strains of $H$. influenrae isolated (three from each hospital) only one was capsulate; it belonged to Pittman's type e. Pneumococci (alpha-haemolytic, optochin-sensitive organisms of appropriate colonial appearance) were recovered, in small numbers only, from two specimens, and various Gram-negative bacilli of intestinal type, mostly in mixed culture, from eight specimens.

Pneumonia.-Admission swabs were received from 22 children with pneumonia in the Royal Victoria Infirmary and four in Walkergate Hospital. Staph. aureus was grown from two children in the infirmary; in each case the organism was sensitive to most antibiotics, and was not of an epidemiologically significant phage type. One of these patients (Case 4) died shortly after admission, and a Staph. aureus similar to that from his admission swab was isolated from a post-mortem lung swab. H. influenzae type $b$, a type which is capable of causing pneumonia (Alexander et al., 1942), was isolated from one child in the Royal Victoria Infirmary, and non-capsulate haemophili were isolated from three of the four Walkergate patients (from both transport media in each case). No haemolytic streptococci or pneumococci were found. Gram-negative bacilli of intestinal type were isolated from five patients.

\section{Virology}

Table II shows the combined results of virus serology and virus isolation. It illustrates that viruses were isolated from $31 \%$ of all cases of bronchiolitis and $33 \%$ of all cases of pneumonia. Table III demonstrates the viruses concerned that

$$
\text { TABLE II.-Summary of the Cases of Bronchiolitis and Pneumonia }
$$
Showing Evidence of Virus Infection

\begin{tabular}{|c|c|c|c|c|c|c|c|c|c|}
\hline . & & 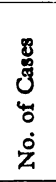 & 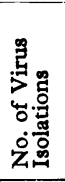 & 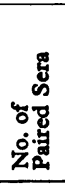 & 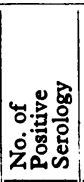 & 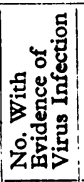 & 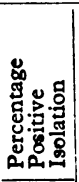 & 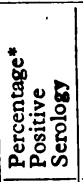 & 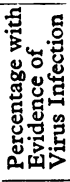 \\
\hline $\begin{array}{l}\text { Bronchiolitis ... } \\
\text { Pneumonia }\end{array}$ & $\ldots$ & $\begin{array}{r}106 \\
45\end{array}$ & $\begin{array}{l}33 \\
15 \\
\end{array}$ & $\begin{array}{l}69 \\
13 \\
\end{array}$ & $\begin{array}{r}41 \\
8\end{array}$ & $\begin{array}{l}66 \\
19 \\
\end{array}$ & $\begin{array}{l}31 \\
33 \\
\end{array}$ & $\begin{array}{l}59 \\
61 \\
\end{array}$ & $\begin{array}{l}62 \\
42 \\
\end{array}$ \\
\hline Total & $\cdots$ & 151 & 48 & 82 & 49 & 85 & 32 & 60 & 54 \\
\hline
\end{tabular}

* Of those from whom paired sera were received.

TABLE III.-Evidence of Virus Infection in Bronchiolotis and Pneumonia and Month-by-month Variation

\begin{tabular}{|c|c|c|c|c|c|c|c|c|c|}
\hline & Nov. & Dec. & Jan. & Feb. & Mar. & Apr. & May & June & Total \\
\hline $\begin{array}{c}\text { Bronchiolitis } \\
\text { No. of cases } \\
\text { R.S.V. .. } \\
\text { Adenovirus } \\
\text { Enterovirus } \\
\text { Pneumonia } \\
\text { No. of cases } \\
\text { R.S.V. ... } \\
\text { Adenovirus } \\
\text { Enterovirus } \\
\text { Herpes sim- } \\
\text { plex } . .\end{array}$ & $\begin{array}{l}33 \\
3(14) \\
4^{*} \\
3 \ddagger \\
15 \\
2(3) \\
1 \\
1\end{array}$ & $\begin{array}{l}33 \\
3(10) \\
2(1) \\
1 \\
\\
1 \text { (1) } \\
1 \text { 1t }\end{array}$ & $1^{(1)}$ & $\begin{array}{l}12 \\
5(2) \\
1 \\
1+ \\
1^{3}\end{array}$ & $4^{8}$ & $2^{5}$ & $1^{1}$ & $1^{1}$ & $\begin{array}{l}106 \\
21(32) \\
7(1) \\
5 \\
45 \\
6(5) \\
6 \\
2 \\
1\end{array}$ \\
\hline Total $\quad$. & $14(17)$ & $9(12)$ & $6(6)$ & $8(2)$ & 5 & $3(1)$ & 1 & 2 & $48(38)$ \\
\hline
\end{tabular}

N.B.- Numbers in parentheses are the numbers of children from whom virus was not isolated but who gave serological evidence of infection.

* One adenovirus isolated from child with rising titre

t One enterovirus isolated from child with R.S. R.

winter and shows their distribution month by month. Evidence of rhinovirus infection was sought by tissue-culture methods, but none was found. Ten of the 11 children with pneumonia who had evidence of infection with R.S.V. were under 2 years of age.

\section{Clinical Management}

The value of antibiotics in the treatment of pneumonia is accepted; their place in the treatment of bronchiolitis is not yet clear. There is also uncertainty about the use of oxygen, antispasmodics, sedatives, corticosteroids, digitalis, and aspiration of the respiratory tract. In the 106 children with bronchiolitis in this series conventional treatment was used. The babies were more comfortable when nursed in the sitting position, and tube-feeding was necessary when dyspnoea interfered with bottle-feeding. All received an antibiotic, usually tetracycline. Most, but not all, were given oxygen in an oxygen tent, without any attempt being made to achieve high concentrations. Antispasmodic drugs were administered to half the children but did not appear to help in the acute phase of the illness. Sometimes sedatives were given, either amylobarbitone sodium or chloral hydrate, as they appeared to reduce the risk of exhaustion in very restless infants. Corticosteroids were given to 13 children because their condition was deteriorating despite other measures; two of these children died. Heart failure, as indicated by a rising pulse rate and progressive enlargement and increased firmness of the liver, occurred in eight children with bronchiolitis and three with pneumonia. All 11 were given digitalis and all except one responded satisfactorily; the exception was a child with pneumonia and congenital heart disease, who died (Case 6, Table IV). Tracheostomy was carried out on one child only. 


\section{Outcome}

There were two deaths in the 106 children with bronchiolitis and four in the 45 with pneumonia. Those who recovered did not appear to have residual damage. The case histories of the two children with bronchiolitis who died are given in detail because of our lack of information about causes of death in this disease.

Case 1.-This child, a male aged 5 weeks, had a history of infection of the upper respiratory tract for seren days, and cough and irregular breathing for one day. Just before admission he had a cyanotic episode possibly associated with inhalation of milk. On admission he was cyanosed and irritable, with a respiratory rate of $90 /$ min., chest distension, and occasional crepitations over the left lower lobe. In view of the intense irritability cerebrospinal fluid was examined, and found to be normal. Chest $x$-ray examination showed pulmonary distension. The baby was treated with oxygen, chloramphenicol, hydrocortisone, and intravenous fluids, but died 36 hours after admission. There was no evidence of heart failure. It appeared probable that his death was due to anoxic brain damage resulting from the cyanotic episode, as the respiratory infection seemed to be responding to treatment. Necropsy showed anatomical changes consistent with bronchiolitis, and there was no pneumonia. Histologically the brain was normal. Post-mortem specimens from the heart and lungs were sterile bacteriologically. Virological studies were also negative.

Case 2.-This child, a female aged 14 months, had a history of infection of the upper respiratory tract for two weeks, and troublesome cough and wheeze for six days. She had received penicillin at home, this being changed to tetracycline two days before admission because her condition was deteriorating with increasing breathlessness. On admission she was ill and restless, with a respiratory rate of $80 / \mathrm{min}$., slight cyanosis, temperature $99.8^{\circ}$ F. ( $37.7^{\circ}$ C.), a hyperresonant distended chest, and fine inspiratory crepitations over the lung-fields. Bronchiolitis was diagnosed clinically, and she was treated with oxygen, oxytetracycline, and phenobarbitone. No $x$-ray film was taken on admission. She developed heart failure, and digitalis was given. Steroid therapy was started because of increasing respiratory difficulty. Cyanosis increased, and costal recession was prominent. Emergency tracheostomy was carried out 30 hours after admission, and cloxacillin was given because staphylococcal pneumonia was suspected. Chest $\boldsymbol{x}$-ray examination the next day showed widespread bronchopneumonia, and a swab taken for bacteriological investigation on admission grew Staph. aureus phage type $80 / 81$, resistant to most antibiotics but sensitive to cloxacillin. Four days after admission her tracheal aspirate contained the same staphylococcus and Pseidomonas pyocyanea. She did not respond, and died on the sixth day. Necropsy showed extensive honeycombing of the lungs. Ps. pyocyanea was isolated from the lungs but not Staph. aureus. All virological investigations were negative.

The main facts about the deaths in the pneumonia group are given in Table IV.

\begin{tabular}{|c|c|c|c|c|c|}
\hline Case & 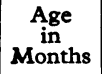 & $\begin{array}{l}\text { Cause } \\
\text { of } \\
\text { Death }\end{array}$ & Associated Features & $\begin{array}{l}\text { Presump- } \\
\text { tive } \\
\text { Pathogens }\end{array}$ & Necropsy \\
\hline 3 & 4 & Pneumonia & $\begin{array}{l}\text { Heart failure. PFibrocystic } \\
\text { disease (Sibling died pre- } \\
\text { viously with similar illness) }\end{array}$ & R.S.v. & No \\
\hline 4 & 5 & $\begin{array}{c}\text { Staphylo- } \\
\text { coccal } \\
\text { pneumonia }\end{array}$ & & $\begin{array}{l}\text { Staph. } \\
\text { aureus }\end{array}$ & Yes \\
\hline 5 & 5 & $\begin{array}{l}\text { Pneumo- } \\
\text { cystis } \\
\text { pneumonia }\end{array}$ & $\begin{array}{l}\text { Hypogammaglobulinaemia. } \\
\text { Heart failure }\end{array}$ & $\begin{array}{l}\text { Pneumo- } \\
\text { cystis } \\
\text { carinii }\end{array}$ & Yes \\
\hline 6 & 13 & $\begin{array}{l}\text { Pneumonia. } \\
\text { Heart } \\
\text { failure }\end{array}$ & $\begin{array}{l}\text { Congenital heart disease. } \\
\text { Patent ductus arteriosus and } \\
\text { atrial septal defect }\end{array}$ & $\begin{array}{l}\text { None } \\
\text { isolated }\end{array}$ & Yes \\
\hline
\end{tabular}

\section{Discussion}

Each year for the past five years about 100 children with bronchiolitis have been admitted to the four hospitals, mainly between October and March. 1963-4 is the first year in which it has been possible to include all cases in a comprehensive survey.
More than four-fifths of the children with bronchiolitis were less than 6 months old, and all below 2 years. Two-thirds of the children with pneumonia were under the age of 2 years, but the rest were distributed up to the age of 12 years.

\section{Bacteriology}

Assessment of the importance of bacteria isolated from admission swabs in the two groups of patients is hampered by scarcity of information about the frequencies with which healthy children in the first year of life carry potential pathogens in their respiratory tracts. Furthermore, $53 \%$ of patients had received some antibiotic treatment before admission. Such treatment was presumably responsible for the almost complete absence of pneumococci from the admission specimens, since these organisms are highly sensitive to the commonly used antibiotics. We do not attach any importance to the finding of Gram-negative bacilli of intestinal type in some specimens, as such organisms are common in the upper respiratory tracts of small children, especially from those receiving antibiotics. As in the surveys by various workers quoted by Beem et al. (1962), no evidence was found to support the claim of Wood et al. (1954) and Sell (1960) that capsulate strains of $H$. influenzae are important in the aetiology of bronchiolitis. The finding of one type $b$ and one type e strain of this species in swabs taken from 64 children is well within normal limits (Masters et al., 1958 ; Turk, 1963). In the present limited bacteriological survey the only organisms isolated from admission swabs which were clearly relevant to the patients' illnesses were the staphylococci from the fatal Cases 2 and 4.

\section{Virology}

Viruses were isolated from nearly a third of the cases in each clinical category, and rising antibody titres for relevant viruses were demonstrated in nearly two-thirds of the cases from which paired serum specimens were received. From the combined results of isolation and serology (Table II), evidence of virus infection was found in $62 \%$ of children with bronchiolitis and in $42 \%$ of those with pneumonia. Naturally, many of the isolations occurred from the children in whom a rising titre was also found. Fewer paired sera were received from children with pneumonia.

Table III shows that R.S.V. was the dominant agent causing bronchiolitis in our locality in 1963-4, although adenoviruses and enteroviruses played a significant part. There was no dominant virus found in pneumonia-R.S.V., adenoviruses, enteroviruses, and herpes simplex all being associated with this illness. Isolation of R.S.V. occurred mainly in infants under 6 months of age in both the pneumonia and the bronchiolitis group, while adenoviruses were distributed throughout all ages. It should be noted that the strains of adenovirus isolated were of the so-called non-epidemic types $1,2,5$, and 6 ; the epidemic types 3,4 , and 7 were not seen.

The results in Table III indicate that R.S.V. was associated with lower respiratory infections throughout the eight months of the investigation, as shown by isolations as well as by serology ; this is in contrast to the findings in Bristol in 1962 (Clarke et al., 1964).

Before a precise virological diagnosis can be made in respiratory disease many difficulties have to be overcome, especially when there is a rapid turnover of cases in acute paediatric beds. In this survey special attention was paid to the collection of cough swabs and their transport unfrozen to the laboratory, this being essential for the isolation of R.S.V. Follow-up appointments were not always kept and so convalescent sera could not be obtained in every case.

Further studies over subsequent winters are required to see whether the same viruses are consistently responsible for bronchiolitis and pneumonia among children in this area. 


\section{Management of Bronchiolitis}

The following views from experienced workers express the contradictions and uncertainties which exist in relation to the treatment of bronchiolitis.

"However, anoxia of varying degree has become more prominent, and is probably now the main cause of death, largely because bronchiolitis, which is becoming increasingly common in infants under the age of 1 year, does not respond to antibiotic therapy, and often produces a suffocative picture" (Morrison, 1955).

" Oxygen is vitally important in bronchiolitis, and there is little convincing evidence that any other therapy is consistently or even occasionally useful " (Reynolds and Cook, 1963).

"In spite of advances so far made it is true to say that we are still ignorant of the amount and frequency of secondary bacterial infection, and of the exact cause of death ..." (Disney et al., 1960).

"We believe that secondary bacterial infection is almost inevitable, probably as a result of commensal organisms from the upper respiratory tract gaining access to an already inflamed mucous membrane" (Heycock and Noble, 1962).

From our own experience, a study of the literature, and conversations with colleagues, we feel that we can begin to separate facts from impressions and so to work towards a rational treatment of this disease.

Oxygen.-Reynolds (1963a, 1963b) has shown by arterial sampling that hypoxia was present in all the children with bronchiolitis that he examined and that this could be corrected by oxygen concentrations of $40 \%$. The first essential, therefore, for any child with acute bronchiolitis is oxygen.

Antibiotics.-Bronchiolitis is due to R.S.V. and other viruses, all of them resistant to the known antibiotics. Antibiotic treatment of this condition is therefore not directed at eliminating the causative organism ; its only possible function is to prevent or treat secondary bacterial infection. It is now an established therapeutic habit to give antibiotics routinely to all patients with this disease, but we believe that this should be reconsidered. The arguments advanced in its favour are that bronchiolitis is not always readily distinguished from pneumonia, for which antibiotic treatment is indicated ; that it is impossible to predict which cases will be complicated by bacterial invasion; and that since antibiotics will do no harm it is simpler to give them to all children with bronchiolitis or pneumonia than to attempt to be selective. Such a policy may give a sense of security to a busy paediatrician, but the premises on which it is based are not self-evident. In particular, as Bywaters (1960) has emphasized, the attempt to prevent bacterial complications of virus infections by giving antibiotics may result in rapid changes in the bacterial flora, so that if bacterial invasion does occur the responsible organisms are already resistant to the antibiotics used. We believe that a sound case can be made for not giving antibiotics as an initial routine but reserving them for cases in which there is evidence of bacterial invasion or from which Staph. aureus, the bacterial species with the greatest pathogenic potential in this context, has been isolated. At least in large hospitals it should be possible for chest $x$-ray films to be taken immediately on admission, and for information about the isolation and antibiotic-sensitivity patterns of bacteria from the respiratory tract to be available within 24 hours. In the absence of clinical, radiological, or bacteriological indications for their use, antibiotics could then be withheld. A change in management of this kind would require carefully controlled comparison with routine antibiotic treatment. However, we suspect that the antibiotic habit is too strongly established for this to be acceptable at present, and as a first step towards a more discriminatory approach preliminary trials might be undertaken of the use of antibiotics routinely for the first 48 hours and their withdrawal at that stage if there was no clinical, radiological, or bacteriological justification for their continuance.

Other Measures in Treatment.-We agree with Heycock and Noble (1962) that heart failure is an important complication of bronchiolitis, and digitalis a valuable remedy. We feel that a descending liver should not be too readily ascribed to mechanical depression by pulmonary distension, especially when it becomes increasingly firm and is accompanied by a rising pulse. There is no evidence that corticosteroids, antispasmodics, or tracheobronchial aspiration are of value in the treatment of bronchiolitis. There may be some general justification for giving corticosteroids to young infants who are severely ill, and they appear to have an antispasmodic effect, but the constitutional benefit must be balanced against the risk of masked virus or bacterial dissemination. We agree with the emphasis laid by Disney et al. (1960) on the importance of dehydration and the need to maintain an adequate fluid intake. Tube-feeding with clear fluids is usually wise for the first 24 hours. For the occasional infant who remains restless in oxygen, a sedative may prevent exhaustion; amylobarbitone sodium and chloral hydrate are quick and effective.

\section{Management of Pneumonia}

Antibiotics.-In our series evidence of virus infection was found in $42 \%$ of the cases of pneumonia, a figure which does not differ very greatly from that of $62 \%$ for the bronchiolitis group. However, we do not believe that our suggestions about the antibiotic treatment of bronchiolitis apply equally to that of pneumonia. Bronchiolitis is a virus disease, whereas the primary agent of pneumonia may be a bacterium or a virus. It is probable that many cases of bacterial pneumonia never reach hospital precisely because they do receive early antibiotic treatment, whereas we doubt whether such treatment reduces the number of cases of bronchiolitis needing hospital admission. Furthermore, there is clear evidence from therapeutic trials that routine antibiotic treatment is beneficial in pneumonia (M.R.C., 1951 ; Sheffield Report, 1956), though it is possible that the situation has changed since that time. Though it seems unlikely that antibiotic treatment is helpful, and possible that it is sometimes harmful, in virus pneumonia, this consideration is overridden by the difficulty of determining with certainty and with necessary speed the nature of the causative organism in the individual case.

Other Forms of Treatment.-In other respects management is similar to that of bronchiolitis. Heart failure is uncommon in the absence of congenital heart disease. When it does occur the indications for giving digitalis are the same as in cases of bronchiolitis. Corticosteroids are rarely indicated except for the resuscitation of a moribund child.

\section{Deaths}

That three of the four children who died with pneumonia had congenital abnormalities emphasizes the fact that these are present in a substantial number of children dying from respiratory infection in early childhood. The close association of Pneumocystis carinii pneumonia with hypogammaglobulinaemia has recently been illustrated again by Marshall et al. (1964). The diagnosis in our case was suspected before death and the presence of hypogammaglobulinaemia established, but the definitive diagnosis was made at necropsy by Dr. T. Bird. The total duration of this child's illness was two weeks.

Despite the large number of fatal cases of bronchiolitis that have occurred in recent years, the precise causes of death are often in doubt, and the two cases described here illustrate the dilemma. The first patient, an infant of 5 weeks, died in the acute phase, and death could have been due to anoxia or possibly to viraemia, though no evidence of virus infection was obtained. It seemed unlikely that bacteria played any part, and cultures of blood and lung tissue collected after death were sterile. In the second child death was due to staphylococcal pneumonia. It could be argued that this should have been the diagnosis on 
admission, but the finding of a hyperresonant distended chest and striking chest recession suggested bronchiolitis. Unfortunately no chest $x$-ray film was taken on admission; the importance of taking such a film in every case of bronchiolitis is illustrated by this case. Deaths from bronchiolitis have not been described as fully in the literature as their importance merits ; more detailed clinical, virological, bacteriological, and pathological studies are needed if we are to achieve rational and effective treatment for this condition.

\section{Summary}

Virological studies of 106 children with bronchiolitis and 45 with pneumonia are reported. Viruses regarded as responsible for the disease were identified in $62 \%$ of the cases of bronchiolitis, R.S.V. being the dominant agent. Evidence of virus infection was also found in $42 \%$ of the children with pneumonia.

Bacteriological studies of cough swabs taken on admission from 39 of the cases of bronchiolitis and 26 of those with pneumonia are reported. Pathogenic bacteria were isolated from a minority and their incidence did not exceed figures available for healthy children. No evidence was found for the view that Haemophilus influenzae plays a part in the aetiology of bronchiolitis. Clinical and bacteriological evidence together would suggest that Staph. aureus is the chief bacterial hazard.

The scarcity of information about secondary bacterial infection and the causes of death in bronchiolitis is stressed. An appraisal has been attempted of present attitudes to therapy, and suggestions are made for a more discriminating approach for the use of antibiotics in the treatment of bronchiolitis.

We would like to thank Professor S. D. M. Court for his interest and help. Professor C. A. Green has also been closely associated with this investigation. We are indebted to Drs. E. G. Brewis, G. Davison, W. D. Elliott, R. H. Jackson, F. J. W. Miller, and T. C. Noble for free access to patients under their care, and for the use of clinical records; and to the registrars-Drs. Elizabeth
Elliott, Valerie Gunn, Jennifer Hardy, Joan Taunch, Margaret Taylor, B. Macnamara, and D. C. Sharde-for their help. We wish to thank Dr. T. Bird for performing the necropsies, Dr. J. Kennedy for help with bacteriology, and Miss J. McQuillin, F.I.M.L.T., B.Sc., for assistance in a variety of ways.

This work has been aided by a grant from the Scientific and Research Subcommittee of the Royal Victoria Infirmary, for which we are grateful.

\section{REPERENCES}

Adams, J. M., Imagawa, D. T., and Zike, K. (1961). F. Amer. med. Ass., 176, 1037.

Alexander, H. E., Ellis, C., and Leidy, G. (1942). F. Pediat., 20, 673.

Andrew, J. D., and Gardner, P. S. (1963). Brit. med. F., 2, 1447.

Bywaters, E. G. L. (1960). Brit med. Bull., 16, 47.

Beem, M., Wright, F. H., Fasan, D. M., Egerer; R., and Oehme, M. (1962). F. Pediat., 61, 864.

Chanock, R. M., Hyun, W. K., Vargosko, A. J., Deleva, A., Johnson, K.M., Cumming, C., and Parrott, R. H. (1961). J. Amer., med. Ass., 176, 647.

Clarke, S. K. R., Corner, B. D., Gambier, D. M., Macrae, J., and Peacock, D. B. (1964). Brit. med. F., 1,1536

Disney, M. E., Sandiford, B. R., Cragg J., and Wolff, J. (1960). Ibid., 1, 1407.

Gardner, P. S., Elderkin, F. M., and Wall, A. H. (1964). Ibid., 2, 1570. Stanfield, J. P., Wright, A. E., Court, S. D. M., and Green, C. A. (1960). Ibid., 1, 1077.

Heycock, J. B., and Noble, T. C. (1962). Ibid., 2, 879.

Holzel, A., Parker, L., Patterson, W. H., White, L. L. R., Thompson, K. M., and Tobin, J. O'H. (1963). Lancet, 1, 295.

Marshall, W. C., Weston, H. J., and Bodian, M. (1964). Arch. Dis. Childh., 39, 18.

Masters, P. L., Brumfitt, W., Mendez, R. L., and Likar, M. (1958). Brit. med. F., 1,1200 .

Medical Research Council (1951). Ibid., 2, 1361.

Morrison, B. (1955). Lancet, 2, 737.

Morrison, B. (195). Lancet, 2, 737.

Pal, S. R., McQuillin, J., and Gardner, P. S. (1963). F. Hyg. (Lond.),
Registrar-General, Statistical Review of England and Wales (1963).
Reilly, C. M. Stokes, J., iu. McClelland, L. Confeld,

Reilly, C. M., Stokes, J., jun., McClelland, L., Cornfeld, D., Hamparian, 264, V., Ketler, A., and Hilleman, M. R. (1961).

Reynolds, E. O. R. (1963a). Brit.

and Cook, C. D. (1963). Ibid., 63, 1205

Sell, S. H. W. (1960). Amer. F. Dis. Child., 100, 7

Sheffield, City General Hospital Report (1956). Brit. med. 7., 2, 1146.

Taylor-Robinson, D., and Bynoe, M. L. (1964). Ibid., 1, 540 .

Taylor-Robinson, D., and Bynoe, M. L. (1964).

Turk, D. C. (1963). F. Hyg. (Lond.), 61, 247. 126,358

Wood, S. H., Buddingh, G. J., and Abberger, B. F. (1954). Pediatrics, 13, 363 .

\footnotetext{
* Department of Medicine, University of Bristol, at Bristol Royal Infirmary.

t Bristol Eye Hospital

‡ Department of Otorhinolaryngology, Bristol General Hospital.
}

removal of the pituitary, and Joplin et al. (1962), using pituitary ablation by yttrium implantation.

The present report concerns 15 patients with diabetic retinopathy treated by trans-sphenoidal hypophysectomy in the United Bristol Hospitals during the period 1960-4.

\section{Material}

Since 1960 all patients attending the diabetic clinic at Bristol Royal Infirmary with severe haemorrhagic diabetic retinopathy threatening vision were considered for hypophysectomy. Of 20 patients who came into this category 15 were finally operated upon. Of the five not treated three were unwilling to have the operation, one was thought to have 